\title{
Thermal modeling of the SW Ryukyu forearc (Taiwan): Implications for the seismogenic zone and the age of the subducting Philippine Sea Plate (Huatung Basin)
} \author{
Gutscher M.-A. ${ }^{1}$, Klingelhoefer Frauke ${ }^{2}$, Theunissen T. ${ }^{3}$, Spakman W. ${ }^{4,5}$, Berthet T. ${ }^{6}$, Wang T.K. ${ }^{7}$,
}

${ }^{1}$ University of Brest, CNRS, IUEM, Laboratoire Domaines Océaniques, Plouzane, France

${ }^{2}$ Ifremer Department of Marine Geosciences, France

3 University of Bergen Department of Earth Science, Norway

${ }^{4}$ Utrecht University, Dept. of Earth Sciences, Utrecht, The Netherlands

${ }^{5}$ Centre of Earth Evolution and Dynamics (CEED), Univ. of Oslo, 0316, Norway

${ }^{6}$ Uppsala University Department of Earth Science, Sweden

${ }^{7}$ National Taiwan Ocean University, Department of Geophysics, Taiwan

\begin{abstract}
:
Subduction mega-thrust earthquakes in the SW Ryukyu trench pose a seismic and tsunami hazard. One of the objectives of this study is to estimate the downdip width of the seismogenic zone using numerical modeling to determine the temperature distribution along the plate interface. However, this approach depends strongly on the thermal parameters of the subducting slab. While the Philippine Sea plate (PSP) subducting beneath the central and eastern Ryukyu arc is of Eocene age (35-50 Ma), its age west of the Gagua Ridge is uncertain, with proposed ages ranging from Lower Cretaceous (140 $\mathrm{Ma}$ ) to Upper Eocene (35 Ma). Since the sparse available heat flow data are insufficient to resolve this debate, both end-member hypotheses are tested as input parameters. We examined two transects at $122.5^{\circ} \mathrm{E}$ and $123.5^{\circ} \mathrm{E}$ on either side of the N-S trending, 4-km high, Gagua Ridge. The shallow forearc geometry is obtained from wide-angle seismic data. The deep slab geometry was obtained from hypocenter distribution and tomography. For an Eocene slab age, we obtain a $100 \mathrm{~km}$ and $110 \mathrm{~km}$ wide seismogenic zone (between the $150{ }^{\circ} \mathrm{C}$ and $350{ }^{\circ} \mathrm{C}$ isotherms) west and east of Gagua Ridge, respectively. This is in good agreement with the observed distribution of hypocenters. Using a Cretaceous slab west of Gagua Ridge predicts a deep seismogenic zone (25 km-60 km depth), inconsistent with observed thrust earthquakes. Tomographic images at $122.5^{\circ} \mathrm{E}$ and $123.5^{\circ} \mathrm{E}$ show a similar slab thickness of $70-80 \mathrm{~km}$ suggesting that the oceanic lithosphere has a young (Eocene) thermal age. The westernmost PSP (Huatung Basin) may have been thermally rejuvenated by mantle convection near the slab corner. The tectonic history since $6 \mathrm{Ma}$ (transition from subduction to collision beneath Taiwan) may have also perturbed the thermal structure.
\end{abstract}




\section{Highlights}

- Numerical modeling of forearc thermal structure performed for the SW Ryukyu subduction $>$ Two transects examined at $122.5^{\circ} \mathrm{E}$ and $123.5^{\circ} \mathrm{E}$, west and east of Gagua Ridge S Slab age of westernmost Philippine Sea plate uncertain - Modeling results indicate a $100-110 \mathrm{~km}$ wide seismogenic zone, in agreement with thrust earthquakes Modeling and tomographic images suggest Huatung basin has young Eocene thermal age. Huatung basin lithosphere possibly rejuvenated by mantle flow or recent tectonics

Keywords : Subduction, Finite-element modeling, Forearc thermal structure, Seismogenic zone 


\section{Introduction and geodynamic setting}

Megathrust earthquakes occurring in subduction zones pose a long-term seismic hazard and tsunami hazard to inhabited regions nearby. Some subduction margins like Nankai (Ando 1975; Kumagai, 1996), Cascadia (Satake et al., 1996; Clague, 1997; Goldfinger et al., 2003), NW Sumatra (Lay et al., 2005; Stein and Okal, 2005; Monecke et al., 2008; Jankaew et al., 2008), or Central Chile (Moreno et al., 2010; Metois et al., 2012) have a known history of long periods of quiescence, punctuated by great mega-thrust earthquakes with magnitudes 89. However, other subduction zones where abundant strong to very strong earthquakes (magnitudes 7-8) occur, can also be the site of catastrophic mega-thrust earthquakes like NE Honshu (Simons et al., 2011), the Kurile-Kamchatka trench or the Aleutian arc (McCaffrey, 2008). Since the size of the rupture zone together with the co-seismic slip determine the magnitude of an earthquake, a first estimate of maximum earthquake size can be obtained by determining the dimensions of the interplate seismogenic zone. The portion of the plate boundary fault considered to be "seismogenic" is partially or completely locked during long periods of time (decades to centuries) accumulating elastic strain, which is suddenly released during an earthquake. In the absence of recent megathrust earthquakes observed by seismographs, accelerometers, and geodetic stations, it is still possible to estimate the size of the seismogenic zone using indirect methods. One of these indirect methods is numerical modeling of forearc thermal structure, since the range over which quartzo-feldspathic rocks (like those in suduction zones) exhibit stick-slip behavior is considered to be between $150^{\circ} \mathrm{C}$ and $350^{\circ} \mathrm{C}$ (Hyndman and Wang, 1995; Oleskevich et al., 1999).

We apply this method to examine the SW end of the Ryukyu subduction zone near Taiwan. First we use wide-angle seismic data to provide information on the geometry and structure of the oceanic crust, forearc and back-arc. Together with earthquake hypocenters and tomographic images we define the geometry of finite-element models, which are then used to calculate the forearc thermal structure. One of the primary objectives of this study is to determine the temperature distribution along the plate boundary fault of this subduction 
zone in order to estimate the thermally predicted limits of the seismogenic zone. These results will be compared to the observed distribution of hypocenters and thrust type earthquakes and the calculated surface heat flow will be compared to available heat flow observations.

This work focuses on the SW end of the Ryukyu subduction zone near Taiwan (Fig. 1). In this region the Philippine Sea plate (PSP) moves in a WNW direction with respect to Eurasia at a velocity of about 8cm/y (Seno et al., 1993; Yu et al., 1997). South of Taiwan, this convergence is accommodated by a N-S trending subduction zone (the Manila trench), where the South China Sea oceanic lithosphere subducts eastwards beneath the PSP, generating the N-S trending Luzon volcanic arc (Suppe, 1981; Malavieille et al., 2002). Thus, the orogen and current tectonics of Taiwan result from the transition from the subduction of the South China Sea to the collision with the Luzon volcanic arc of the subducting continental passive margin of the South China block beneath Taiwan (Suppe, 1981; Ho, 1986; Tsai, 1986; Wu et al., 1997; Teng et al., 2000; Lallemand et al., 2001; Malavielle and Trullenque, 2009). To the east of Taiwan, plate convergence is absorbed across the Ryukyu trench arc system, with the trench veering from a NE-SW orientation near Japan to an E-W orientation at its SW termination next to Taiwan defining another transition from subduction to collision (Lallemand et al., 1999; 2001). In this portion of the PSP there is a major N-S trending basement high, the Gagua Ridge (Fig. 1), with a height culminating at 4-5 km (with respect to the adjacent basement). This feature is thought to be a reactivated fracture zone and may have acted as a plate boundary in the past (Deschamps et al., 1998; Eakin et al., 2015). Unfortunately, the age of the subducting slab for the portion of the PSP west of Gagua Ridge (Huatung Basin) is not well known, with estimates ranging from upper Eocene in age (33 - 44 Ma) (Hilde and Lee, 1984 (33 - $42 \mathrm{Ma}$ ) (Doo et al., 2015) to lower Cretaceous (119 - 131Ma) (Deschamps et al., 2000; Deschamps and Lallemand, 2002) (140 Ma) (Lallemand et al., 2013). This age uncertainty can be expected to strongly influence the thermal structure predicted by the numerical modeling and thus the end-member hypotheses (35 Ma and 140 Ma) will be tested here.

Geodetic studies show that the Ryukyu continental fore-arc block moves independently with respect to Eurasia due to active extension in the Okinawa trough back-arc basin (Nakamura, 2004). The resulting oblique subduction of the PSP beneath the Ryukyu block is estimated to reach $14 \mathrm{~cm} / \mathrm{yr}$ (Lallemand et al., 2013) and the orthogonal subduction velocity is about $9 \mathrm{~cm} / \mathrm{yr}$. Near Taiwan, the Ryukyu subduction is marked by frequent 
moderate to strong earthquakes (Kao, 1998; Kao et al., 1998; Font and Lallemand, 2009; Theunissen et al, 2010). West of Gagua ridge most of the well-known thrust events produced by slip along the subduction interface occurred between $10 \mathrm{~km}$ and $35 \mathrm{~km}$ depth (Kao et al., 1998; Lallemand et al., 2013). The long-term seismic hazard of the Ryukyu subduction remains an open question, with some authors suggesting that it bears some geometric similarities to the Sumatra-Andaman subduction zone (Hsu and Sibuet, 2005; Lin et al., 2014).

Heat flow data are available in the study area from several sources. Older marine and terrestrial heat flow values were obtained from the Global Heat Flow Database ( http://www.heatflow.und.edu ). The heat flow pattern observed on the map (Fig. 2) can be subdivided into three regions; an oceanic domain (on the PSP south of the Ryukyu Trench), a forearc block and the Okinawa Trough backarc. In the oceanic domain, heat flow is typically $40-60 \mathrm{~mW} / \mathrm{m}^{2}$ though a few scattered values can exceed $100 \mathrm{~mW} / \mathrm{m}^{2}$ (Fig. 2). The Ryukyu forearc block has few data (only three values west of $126.5^{\circ} \mathrm{E}$ ) and these indicate low heat flow (between 30 and $60 \mathrm{~mW} / \mathrm{m}^{2}$ ). The two values east of $126.5^{\circ} \mathrm{E}$ are higher, $60-80$ $\mathrm{mW} / \mathrm{m}^{2}$. The former low values are consistent with a fore arc thermal low. The latter are somewhat higher than expected for a forearc, but may be influenced by local fluid flow. Finally, the Okinawa Trough back arc region shows a large scatter of values from below 20 $\mathrm{mW} / \mathrm{m}^{2}$ to well over $300 \mathrm{~mW} / \mathrm{m}^{2}$. The most common values range from $100-160 \mathrm{~mW} / \mathrm{m}^{2}$. This is consistent with high heat flow reported for other back arcs worldwide (Currie and Hyndman, 2006). The extremely high values (several hundred $\mathrm{mW} / \mathrm{m}^{2}$ ) are located close to volcanic centers in the backarc (Fig. 2). There are only two heat flow data observations on the PSP west of Gagua Ridge (in the Huatung Basin), with one nearly on the ridge. These two observations fall within the range of values observed on the remainder of the PSP (Fig. 2). However, the paucity of observations makes it difficult to confirm or disprove the two competing hypotheses for the age of the Huatung basin (Eocene or Cretaceous).

\section{The limits of the seismogenic zone}

One of the major challenges in earth science is to understand how and where earthquakes are generated along the subduction plate interface (Byrne et al., 1988; Tichelaar and Ruff, 1993; Pacheco et al., 1993 Oleskevich et al., 1999; Wada and Wang, 2009; Lay, 
2015). A popular model suggests that the uppermost portion of the plate boundary, below the accretionary wedge behaves aseismically primarily due to the presence of high porosity, fluid rich sediments (Byrne et al., 1988). While some margins have little to no accretionary wedge, it seems likely that high fluid pressure within sediments along the plate interface can have an impact on seismogenesis (Hubbert and Rubey, 1959; Davis et al., 1983; Byrne and Fisher, 1990; Moore, et al., 1995; Saffer and Beakins, 2002). Other studies on the updip limit proposed a rheological control due to changes in the behavior of clay minerals and sediments as these undergo low-grade metamorphic reactions and diagenesis. Two important transitions, opal to quartz, and smectite to illite and chlorite, occur in the accretionary wedge (or shallow forearc) at temperatures of $100-150^{\circ} \mathrm{C}$ with the higher-grade minerals exhibiting a stick-slip rheology permitting seismogenic behavior (Vrolijk, 1990; Moore and Saffer, 2001).

For the downdip limit, there are two competing models; a thermal control due to the transition to dislocation creep at high temperatures (Scholz, 1990) or alternatively, that the presence of a highly serpentinized mantle wedge, can permit aseismic sliding, and thus define the downdip limit of seismogenic behavior (Hyndman et al., 1995). Global statistical analyses of subduction megathrust earthquakes indicate that on average, the downdip limit occurs at depths of $40 \pm 5 \mathrm{~km}$ (Tichelaar and Ruff, 1993) or $51 \pm 8 \mathrm{~km}$ (Heuret et al., 2011). The more recent and exhaustive compilation suggests that the downdip limit commonly exceeds the fore-arc Moho depth and thus a serpentinized mantle wedge is seldom the controlling factor (Wada and Wang, 2009; Heuret et al., 2011).

For many margins which have been investigated by numerical modeling of forearc thermal structure (SW Japan, Cascadia, Chile, Mexico, Alaska, Sumatra), there is good agreement between the thermally predicted updip and downdip limits, and these limits as obtained from other methods (e.g. - source-time studies, aftershock studies, geodetic studies, tsunami modeling) (Hyndman et al., 1995; Hyndman and Wang, 1995; Oleskevich et al., 1999; Currie et al., 2002; Gutscher and Peacock, 2003; Klingelhoefer et al., 2010).

\section{Wide-angle seismic models}

Two wide-angle seismic models were used to constrain the shallow parts of the thermal model (Wang et al., 2001; Wang et al., 2004; Klingelhoefer et al., 2012). These profiles are located west of Gagua Ridge (Fig. 3). Profile EW9509-1 was acquired in 1995 during the 
TAICRUST experiment and the ACTS profile as part of the TAIGER experiment in 2009 (Fig. 3). Both studies used the forward and inversion modeling code "Rayinvr" (Zelt and Ellis, 1988; Zelt and Smith, 1992; Zelt, 1999) resulting in overall similar velocity models (Figure 4). The crustal structure east of Gagua Ridge is less well known and sediment thickness at the trench and depth to basement values were obtained from published studies (Lester and McIntosh 2012; Van Avendonk et al., 2014; Eakin et al., 2015).

Along the EW9509-1 profile, the sedimentary thickness increases from 2-3 km at the trench, to $7-8 \mathrm{~km}$ towards the north, resulting from the accretion of the sediments overlying the Philippine Sea plate to the overlying forearc (Wang et al., 2001). The boundary between the subducting oceanic plate and the Ryukyu Block basement starts at a depth of $5 \mathrm{~km}$ at $\mathrm{km} 50$ (Fig. 4), continues to a depth of $13 \mathrm{~km}$ below the center of the Nanao Basin (km 200), and reaches a depth of $22 \mathrm{~km}$ below the shallow portion of the Ryukyu Block slope ( $\mathrm{km} \mathrm{220)}$.

Along the ACTS profile, the sedimentary thickness on the oceanic plate is about $2-3 \mathrm{~km}$, increasing to $10 \mathrm{~km}$ in the accretionary wedge (Figure 4B). The thickness of the oceanic crust is about 5-6 km, slightly thinner than normal oceanic crust of $7.2 \mathrm{~km}$ thickness. On this line the backstop is characterized by a very steep dip and characterized by low velocities, possibly due to erosion and fracturing.

West of Gagua Ridge, the Philippine Sea plate subducts northward underneath the Ryukyu Block showing a slight deflection. This deflection beneath the forearc buttress may reveal compression and/or overloading. Further north, crustal thickness of the Ryukyu Block is about $25 \mathrm{~km}$, thinning down to $15 \mathrm{~km}$ in the Okinawa Trough, as seen along the best constrained seismic refraction line (Fig. 4A). The upper mantle material underlying the oceanic plate is characterized by relatively low seismic velocities, which might be due to the partial serpentinization of the mantle peridotites by water passing through faults in the oceanic plate. The faults may be generated by the bending of the subducting plate before subducting, or possibly due to the original seafloor spreading fabric. Comparison of both wide-angle models shows good agreement in the sedimentary and crustal thicknesses. The difference in the apparent dip angle of the subducting plate can be explained by different orientations of the location of the profiles relative to the subduction zone. 


\section{Numerical modeling of the Ryukyu fore-arc thermal structure}

We applied finite-element modeling of forearc thermal structure in order to determine the temperature distribution along the plate interface and thereby try to predict the updip and downdip limits of the seismogenic zone. This approach is based on models, which consider temperature as the primary control of stick-slip rheological behavior that lead to earthquake rupture (Hyndman and Wang, 1993; Hyndman et al., 1997; Peacock and Wang, 1999; Gutscher and Peacock, 2003). The geometry of the subducting oceanic crust and the upper plate (down to $20-25 \mathrm{~km}$ depth) is constrained primarily by the wide-angle seismic data presented above (Wang et al., 2001; 2004; Klingelhoefer et al., 2012) (Fig. 4) and by available multi-channel seismic data as well (Font et al., 2001; 2009; Wang et al., 2004). The deeper geometry is obtained from the distribution of Wadati-Benioff zone hypocenters. For the earthquake hypocenters we consider two different catalogs the NEIC-PDE catalog (19732014) (Fig. 1, Fig. 3) and a relocated Taiwan earthquake catalog (Theunissen et al., 2012a) (Fig. 4). The two hypocenter cross-sections show the N-ward dipping band of earthquakes. The upper limit of these hypocenters visible down to about $50-60 \mathrm{~km}$ depth appears to represent the plate boundary interface (Fig. 4) (Font and Lallemand, 2009; Theunissen et al., 2012a,b). Earthquakes below this envelope are intra-slab earthquakes, which can be followed down to $100 \mathrm{~km}$ depth in these cross sections (Fig. 4). For the deeper geometry and overall slab dip, tomographic cross sections were also used (Fig. 5 A, B) from the global P-wave velocity model UU-P07 (Amaru, 2007; Hall and Spakman, 2015). These images show a somewhat more steeply dipping slab $\left(60^{\circ}\right)$ at depth for the western cross-section (Fig. 5A) and a more moderately dipping slab $\left(45^{\circ}\right)$ at depth further east (Fig. 5B). Together, these data are used to construct the geometry of the 2-D finite element grid (Fig. 6).

We used the "new" version of finite element (FE) software "PGCtherm", developed by Kelin Wang, Jiangheng He and co-workers (Currie et al., 2004; Wada and Wang, 2009). For the Ryukyu arc, we constructed several $500 \mathrm{~km}$ long FE-models consisting of 6 different layers; upper crust, lower crust, lithospheric mantle of the upper plate, the convecting asthenospheric wedge, the oceanic crust of the subducting plate and the oceanic mantle lithosphere of the subducting plate (together the latter two constitute the downgoing slab) (Figure 6). The models include induced convection (corner flow) in the asthenospheric wedge, with a maximum depth of decoupling along the plate interface of $60 \mathrm{~km}$ (see white dashed line on Fig. 6) (for comparison see also Wada and Wang, 2009). Mantle flow was 
permitted up to $50 \mathrm{~km}$ depth below the upper plate backarc. Model runs were performed with both an iso-viscous asthenospheric wedge as well as a non-linear viscosity (temperature and pressure dependent viscosity) wedge (Wada and Wang, 2009). The effects of shear heating along the subduction interface were included for a modest effective friction coefficient of 0.03 as discussed in recent modeling studies (Wada et al., 2008; Wada and Wang, 2009). Thermal conductivity in the mantle and oceanic crust is $3.1 \mathrm{~W} / \mathrm{mK}$ consistent with the GDH1 model (Stein and Stein, 1992) and thermal conductivity in the continental crust is $2.5 \mathrm{~W} / \mathrm{mK}$ (Peacock and Wang, 1999). Radiogenic heat generation in the upper continental crust is 0.6 microWatt $/ \mathrm{m}^{2}$ and in the lower continental crust is $0.4 \mathrm{microWatt} / \mathrm{m}^{2}$.

The initial boundary conditions include: at the left side, oceanic lithosphere isotherms for a subducting oceanic plate of the appropriate age based on the GDH1 thermal cooling model (Stein and Stein, 1992), $0^{\circ} \mathrm{C}$ at the surface and a continental geotherm at the right side boundary (representing the upper plate). The three primary input parameters to the model are thus; the plate geometry, the age of the subducting lithosphere and the subduction velocity. Taking the component of plate motion perpendicular to the margin results in an orthogonal subduction velocity of $9 \mathrm{~cm} / \mathrm{yr}$, which was used for the thermal modeling.

\section{Results of thermal modeling}

The modeled thermal structure is presented in Figure 7 with projected NEIC-PDE earthquake hypocenters in order to use a homogeneous dataset along both lines. For the western profile at $122.5^{\circ} \mathrm{E}$ and a $35 \mathrm{Ma}$ slab age, the $100^{\circ} \mathrm{C}$ isotherm is reached about $12 \mathrm{~km}$ from the trench (Fig. 7a). For the eastern profile the $100^{\circ} \mathrm{C}$ isotherm is only $5 \mathrm{~km}$ from the trench (Fig. 7c). This represents the beginning of the transition zone where seismogenic behavior can be expected to begin. This proximity to the trench appears to be largely due to the insulating effect of the relatively thick sedimentary cover at the trench as was also observed for the NW Sumatra margin (Klingelhoefer et al., 2010). The thermally predicted updip limit is compatible with the distribution of subduction thrust earthquakes, as shallow dipping compressional focal mechanisms are observed $50-100 \mathrm{~km}$ northwards of the trench at $122.5^{\circ} \mathrm{E}$ and $70-80 \mathrm{~km}$ northwards of the trench at $123.5^{\circ} \mathrm{E}$ (Fig. $7 \mathrm{a}, \mathrm{c}$ ). The $350^{\circ} \mathrm{C}$ and $450^{\circ} \mathrm{C}$ isotherms, which are considered to correspond to the downdip limit, are located 150 $\mathrm{km}$ and $165 \mathrm{~km}$, respectively, from the trench axis for the western section (Fig. 7a) and at 145 
$\mathrm{km}$ and $155 \mathrm{~km}$ for the eastern section (Fig. 7c). Most of the shallow ( $<50 \mathrm{~km}$ depth) hypocenters fall between the thermally predicted limits (between $150^{\circ} \mathrm{C}$ and $350^{\circ} \mathrm{C}$ ) if they occurred on the plate interface. Thrust type earthquakes fall predominantly between the $120^{\circ} \mathrm{C}$ and $250^{\circ} \mathrm{C}$ isotherms when projected to the plate interface (Fig. 7a). For the western section and a modeled slab age of $140 \mathrm{Ma}$, the predicted seismogenic zone is $120-165 \mathrm{~km}$ from the trench (between the $150^{\circ} \mathrm{C}$ and $350^{\circ} \mathrm{C}$ isotherms) and much deeper, $25-60 \mathrm{~km}$ deep (Fig. 7b). Examining the distribution of earthquakes from the Taiwan catalog (Theunissen et al., 2012) reveals a similar overall pattern (Fig. 4). The hypocenter distribution is far less scattered than for the PDE catalog (Fig. 7) and clearly defines a plate boundary interface (Fig. 4). This interface can be traced down to about $40 \mathrm{~km}$ depth in both sections, and below this a broader band of intermediate depth earthquakes is observed defining the body of the downgoing slab (Fig. 4, Fig. 7). There is also a very strong activity of shallow crustal earthquakes in the uppermost $10-15 \mathrm{~km}$ occurring below the Ryukyu forearc basins as described in previous work. Based on other earthquake catalogs, most of this seismicity occurred along the subduction interface or within the PSP along the so-called Hoping cluster with mainly thrust events (Font et Lallemand, 2009; Theunissen et al., 2012b; Lallemand et al., 2013) and within the upper-plate formed by Ryukyu forearc along the so-called Nanao cluster with normal events (Konstantinou et al., 2011; Theunissen et al., 2012b; Lallemand et al., 2013) and along the Suao cluster close to Taiwan with mainly strike-slip events (Theunissen et al., 2012b; Lallemand et al., 2013). This shallow seismicity is interpreted as evidence for upper plate deformation and intraslab deformation due to the ongoing collision between the PSP slab and the Eurasian plate beneath and adjacent to Taiwan ( Theunissen et al., 2012b; Lallemand et al., 2013). A joint seismological and geodetic study performed following the 2002 Hualien M7.1 thrust earthquake indicated the presence of Slow Slip Events on the subduction interface between $123.2^{\circ}$ and $124.2^{\circ} \mathrm{E}$ longitude (along the section from Fig. 7C) and strong afterslip (with an equivalent moment magnitude of 7.4) occurring on the plate interface between $122.5^{\circ}$ and $123.2^{\circ} \mathrm{E}$ longitude (along the location of the section from Fig. 7A, B) (Nakamura, 2009). The depth of the interface for the calculated fault surfaces is primarily between 40 and $60 \mathrm{~km}$ depth. This transitional seismic slip behavior seems to be in agreement with the calculated downdip limits obtained from the thermal modeling for a $35 \mathrm{Ma}$ old slab (Fig. 7A, C). 
The thermal models presented here feature mantle convection in the asthenospheric wedge with a non-linear (temperature and pressure dependent) viscosity (Wada and Wang, 2009). Other model runs were performed using the same geometry and slab age and a constant viscosity in the asthenospheric mantle (Fig. 8). A comparison of the thermal structures obtained shows almost no difference $(\leq 10 \mathrm{~K})$ between the two temperature distributions along the shallow plate interface down to $25 \mathrm{~km}$ depth and somewhat cooler temperatures $(50-100 \mathrm{~K}$ cooler) along the plate boundary down to $50 \mathrm{~km}$ depth for the temperature and pressure dependent viscosity. A temperature dependent viscosity produces the greatest differences in the convecting mantle corner $(100-200 \mathrm{~K}$ hotter than for an isoviscous mantle), and in the deeper portion of the upper plate lithosphere (200 - $400 \mathrm{~K}$ cooler at $50-100 \mathrm{~km}$ depth, with respect to an iso-viscous mantle) (Fig. 8). This latter somewhat paradoxical effect (the cooler base of the upper plate lithosphere) has been discussed at length elsewhere (Wada and Wang, 2009), but has little bearing on our study which is focused on the fore-arc temperature structure.

\section{Comparison of observed and calculated heat flow}

The expected heat flow at the surface calculated using the thermal models presented here is shown in Figure 9 a, b. Unfortunately, there are very few heat flow data in the westernmost Philippine Sea west of Gagua Ridge (Huatung Basin). In order to establish the overall heat flow trend, observed data from $122^{\circ} \mathrm{E}$ to $124.5^{\circ} \mathrm{E}$ are projected onto both sections. For the western transect at $122.5^{\circ} \mathrm{E}$, the calculated heat flow for the two different slab ages shows a significant difference only at the southern end of the profiles. A young, $35 \mathrm{Ma}$ slab age would correspond to a background heat flow of about $70-75 \mathrm{~mW} / \mathrm{m}^{2}$, whereas the older, $140 \mathrm{Ma}$ slab age should produce a heat flow of about $40 \mathrm{~mW} / \mathrm{m}^{2}$. For the eastern transect at $123.5^{\circ} \mathrm{E}$ the expected heat flow for the undisturbed oceanic crust is even higher, about $90-95 \mathrm{~mW} / \mathrm{m}^{2}$. The difference between the expected heat flow at the trench, for the same slab age, east and west of Gagua is most likely an effect of the thickness of the trench fill sediments. The few available heat flow observations in the undisturbed oceanic domain (both east and west of Gagua) are in the range $35-105 \mathrm{~mW} / \mathrm{m}^{2}$, with 4 out of 5 values between 35 $\mathrm{mW} / \mathrm{m}^{2}$ and $60 \mathrm{~mW} / \mathrm{m}^{2}$. Such low values west of Gagua are compatible with a Cretaceous age oceanic lithosphere. The unusually low values east of Gagua are likely due to local fluid 
circulation or to a thermal blanketing and cooling effect from rapid sedimentation in this particular environment adjacent to a rapidly growing orogen with high rates of erosion (e.g. Dadson et al., 2003). But with a total of only 10 heat flow values on the incoming Philippine Sea plate in the entire study area (Fig. 2) it is difficult to draw any reliable conclusions on the typical heat flow. The scatter in values is simply too large. The calculated heat flow curves show a similar pattern in all cases, with a general decline from the trench to the forearc with the coolest point located about $120 \mathrm{~km}$ from the trench, where heat flows of $25-35 \mathrm{~mW} / \mathrm{m}^{2}$ are predicted (Fig. 7a,b). In our models we used a hot continental geotherm $\left(90 \mathrm{~mW} / \mathrm{m}^{2}\right)$ for the back-arc as recommended in a recent modeling study (Wada and Wang, 2009). However, the modeled heat flow in the back arc only increases to about $60 \mathrm{~mW} / \mathrm{m}^{2}$ at the arc and then drops to $50 \mathrm{~mW} / \mathrm{m}^{2}$ in the back-arc, which is lower than the surface heat flow typically observed in backarcs (Currie and Hyndman, 2006). This unusually cool back-arc is due to the non-linear viscosity in the asthenospheric wedge, as has been discussed elsewhere (Wada and Wang, 2009). Another way of obtaining high modeled heat flow in the back-arc would be to consider the axis of the Okinawa Trough to be a very young oceanic spreading center (age 0 $\mathrm{Ma})$. This would result in a very high predicted heat flow $\left(>150 \mathrm{~mW} / \mathrm{m}^{2}\right)$. As it stands there are insufficient heat flow observations to favor one model or the other.

\section{Discussion}

A 2-D tomographic cross section oriented E-W and crossing the Gagua Ridge from the global tomographic model UU-P07 (Amaru, 2007; Hall and Spakman, 2015) is shown here (Fig. 10). This global tomographic model is successful in imaging moderately old to old subducting oceanic lithosphere (van Benthem et al., 2013; Chertova et al., 2014; Hall and Spakman, 2015). The E-W cross-section (Fig. 10) as well as the two N-S tomographic crosssections at $122.5^{\circ} \mathrm{E}$ (Fig. 5A) and $123.5^{\circ} \mathrm{E}$ (Fig. 5B) reveal a similarly $70-80 \mathrm{~km}$ thick high P-wave velocity anomaly (the oceanic lithosphere of the incoming plate and the subducting slab) on the undisturbed Philippine Sea plate. The slab dip is somewhat steeper (about $60^{\circ}$ between $100 \mathrm{~km}$ and $300 \mathrm{~km}$ depth) for the western section as expressed by the hypocenter distribution (Fig. 7a,c) with respect to the eastern section (about $45^{\circ}$ between $100 \mathrm{~km}$ and 300 $\mathrm{km}$ depth). Except for the dip, there is no significant difference observed east and west of Gagua Ridge, neither in the N-S sections (Fig. 5 A, B) nor in the E-W cross section (Fig. 10). 
Based on the tomographic images presented here, the apparent lithospheric thickness remains a constant $70-80 \mathrm{~km}$ in all cases on both sides of the Gagua ridge, though the resolution of such global models is rather low in oceanic regions poorly constrained by earthquake raypaths. One tomographic model (Wei et al., 2015) shows a high positive S-wave velocity anomaly at the base of the upper-mantle at the southernmost part of the Ryukyu subduction which could indicate an old lithospheric slab, but it is not associated with a P-wave velocity anomaly. Other P-wave velocity tomographic models examined did not reveal any marked differences at 50 - $100 \mathrm{~km}$ depths below the Western PSP - Huatung basin (east and west of Gagua Ridge) at the resolution of the given models (Koulakov et al., 2014; Huang et al., 2015; Wei et al., 2015)

Our thermal model using an Eocene plate age (35 Ma) predicts a $100-110 \mathrm{~km}$ wide downdip width (between the $150^{\circ} \mathrm{C}$ and $350^{\circ} \mathrm{C}$ isotherms), i.e. between $5-10 \mathrm{~km}$ and $35-50$ $\mathrm{km}$ depth. Such a width brackets the observed hypocenter distribution in general (Figs. 7a,c) and more specifically spans the occurrence of interplate thrust type (shallow dipping compressional) earthquakes (Figs. 7a, c) with the vast majority of earthquakes falling between the $120^{\circ} \mathrm{C}$ and $300^{\circ} \mathrm{C}$ isotherms (when projected to the plate interface). Thrust earthquakes are far more abundant west of the Gagua Ridge than east of the ridge. Using the maximum proposed Cretaceous plate age (140 Ma) the predicted seismogenic zone is much deeper (between 25 and $60 \mathrm{~km}$ depth) and narrower (only $45 \mathrm{~km}$ downdip width). The majority of crustal depth earthquake hypocenters and very nearly all thrust type earthquakes occur above the $150^{\circ} \mathrm{C}$ isotherm predicted by this model, with about $1 / 3$ of such thrust events occurring trenchward of the $100^{\circ} \mathrm{C}$ isotherm. Not a single thrust type earthquake occurs between $180^{\circ} \mathrm{C}$ and $350^{\circ} \mathrm{C}$ for this model (in all cases when hypocenters are projected to the plate interface). It therefore seems highly unlikely that the slab west of Gagua Ridge has a thermal age of 140 Ma. On the basis of these observations and modeling we consider the thermal age of the lithosphere west of Gagua Ridge (the Huatung Basin) to be equivalent to the major part of the PSP (east of Gagua Ridge).

The simplest explanation for a similar and young thermal age is that both portions east and west of Gagua Ridge are Eocene in age. This conclusion conflicts with the Early Cretaceous ages of the gabbros dredged in the southern part of the Huatung Basin (Deschamps et al., 2000). Since no heterogeneity supports a different nature in the oceanic crust of the basin from south to north, we also consider an alternative explanation, which may 
reconcile the apparent conflicting data. It has been suggested that the lithosphere of the western portion of the PSP (Huatung Basin) may have been thermally rejuvenated by interaction with a plume during the Eocene (Deschamps et al., 2000, 2002). Alternatively, the location of the western PSP in the back-arc domain of the Luzon arc, due to asthenospheric convection in the mantle wedge could have also resulted in thermal erosion of the lithosphere. The proximity to the slab edge beneath Taiwan with strong toroidal flow could also produce a similar thermal erosion effect. Determining the tomographic expression of other wellestablished slab edges is a subject that merits examination.

Finally, one could argue that the recent collisional tectonics beneath Taiwan and in the westernmost Ryukyu trench may have produced a strongly transient thermo-mechanical state, which is not well represented by a steady-state thermal modeling approach. Both the westward propagation of the Ryukyu trench along the Ocean-Continent transition of the East China passive continental margin during last 6 Myrs (Lallemand et al., 2001), the current intra-slab deformation involving compression and fragmentation of the PSP beneath the SW Ryukyu forearc (Lallemand et al., 2013), as well as the westward propagation of the Okinawa trough rift (Sibuet et al., 1998) rapidly thinning the upper plate lithosphere, create perturbations in the thermal structure which cannot be adequately modeled using 2-D steady state models. Given the uncertainities described here, the poorly constrained thermal state of the PSP would justify acquisition of additional heat flow data, both east and west of Gagua Ridge.

\section{Conclusions}

Thermal modeling of the SW Ryukyu subduction zone shows a minimum $100-110$ $\mathrm{km}$ (from $150^{\circ} \mathrm{C}$ to $350^{\circ} \mathrm{C}$ isotherms) to a maximum $150 \mathrm{~km}$ downdip width for the seismogenic zone (from $100^{\circ} \mathrm{C}$ to $450^{\circ} \mathrm{C}$ isotherms including transition zones). The modeled thermal structure obtained for a $35 \mathrm{Ma}$ (upper Eocene) slab age is compatible with earthquake hypocenters and the distribution of thrust earthquakes. A 140 Ma slab age would predict a deeper seismogenic zone, which is not in agreement with the hypocenter distribution and presence of thrust type earthquakes. Tomographic images at $122.5^{\circ} \mathrm{E}$ and $123.5^{\circ} \mathrm{E}$ reveal a similar $70-80 \mathrm{~km}$ thick high $\mathrm{P}$-wave velocity anomaly (the oceanic lithosphere of the incoming plate and the subducting slab). There is no significant difference observed east and west of Gagua Ridge, neither in the N-S sections nor in E-W cross sections. We consider it 
likely that the subducting Philippine Sea plate has an Eocene thermal age all along the SW Ryukyu trench.

\section{Acknowledgments}

The GMT software package (Wessel and Smith, 1995) was used for several figures in this paper. We thank Kelin Wang and Jiangheng He for use of the new version of the FEmodeling code PGCtherm. Support from the European Union FP7 project ASTARTE helped fund a visit to the Pacific Geoscience Center (Sidney BC Canada) to allow this collaboration and is gratefully acknowledged. This work was partly supported by the Research Council of Norway through its Centres of Excellence funding scheme, project number 223272.

\section{Figure captions}

Figure 1: General location map of Taiwan-Ryukyu convergent margin with earthquake hypocenters. The location of the geophysical transects investigated in this study are indicated by the black lines. Tomographic cross-sections are shown by green-dashed lines.

Figure 2: Heat flow map of the Taiwan - Ryukyu trench region (colored circles coded according to heat flow: red $=$ high, blue-violet $=$ low). The location of observed and calculated heat flow transects shown in Fig. 8 is indicated.

Figure 3: Map of the SW Ryukyu trench and SW Okinawa Trough region with the location of refraction seismic profiles shown. OBS are indicated by inverted black triangles. Sampling boxes for earthquake hypocenters shown in Fig. 7 are indicated. Bathymetry is from satellite altimetry (Sandwell and Smith, 1995) and multibeam data (Lallemand et al., 1996).

Figure 4: P-wave velocity models from two seismic refraction lines from forward modeling with projected relocated earthquake hypocenters (Theunissen et al., 2012) superposed. (for sampling boxes see Fig. 3) A) The NNE-SSW oriented profile was recorded by 24 OBS; B) The N-S oriented profile at $122.5^{\circ} \mathrm{E}$ was recorded by 8 OBS.

Figure 5: Tomographic cross sections from global travel-time P-wave velocity model (Amaru, 
2007; van Benthem et al., 2013) showing the north dipping Philippine Sea plate (PSP) slab subducting beneath the Eurasian plate at the southernmost Ryukyu trench. (A) N-S crosssection at $122.5^{\circ} \mathrm{E}$ longitude. (B) N-S cross-section at $123.5^{\circ} \mathrm{E}$ longitude.

Figure 6: Finite-element grids for the two modeled transects, indicating primary input parameters (slab geometry, age, velocity) and boundary conditions. Induced convection (corner flow) can occur below the lithospheric mantle (50 km depth) and seawards up to the white dashed line (60 km depth), which is the maximum depth of decoupling (for comparison see also Wada and Wang, 2009).

Figure 7: 2-D thermal models obtained for a non-linear viscosity (temperature and pressure dependent) asthenospheric wedge $\left(100^{\circ} \mathrm{C}\right.$ isotherms shown), earthquake hypocenters from PDE catalog (1973-2014) shown as colored circles and thrust-type earthquakes (from CMT catalog) shown as colored circles with thick black rim (a) Western transect at $122.5^{\circ} \mathrm{E}$ for an Upper Eocene slab age of $35 \mathrm{Ma}$ (b) Western transect at $122.5^{\circ} \mathrm{E}$ for a Lower Cretaceous slab age of $130 \mathrm{Ma}$ (c) Eastern transect at $123.5^{\circ} \mathrm{E}$ for an Upper Eocene slab age of $35 \mathrm{Ma}$

Figure 8: 2-D thermal models of the Western transect at $122.5^{\circ} \mathrm{E}$ for an Upper Eocene slab age of $35 \mathrm{Ma}$, comparing the results for an non-linear viscosity asthenospheric wedge $\left(100^{\circ} \mathrm{C}\right.$ isotherms shown in red - same thermal structure as for Figure 7A), to the results for a temperature-dependent viscosity in the asthenospheric wedge $\left(100^{\circ} \mathrm{C}\right.$ isotherms shown in black). The plate boundary is shown by the green curve.

Figure 9: Observed (red and blue circles) and predicted (colored curve) heat flow along the N$\mathrm{S}$ transects. Solid lines show predicted surface heat flow for a non-linear viscosity asthenospheric wedge (Figs. 7A-C) and modest shear heating (effective friction 0.03), whereas dashed lines are for an isoviscous wedge and zero shear heating. The non-linear viscosity wedge predicts lower heat flow in the back-arc (Wada and Wang, 2009). (A) Western transect at $122.5^{\circ} \mathrm{E}$ longitude. (B) Eastern transect at $123.5^{\circ} \mathrm{E}$ longitude. Blue circles are values located between $122^{\circ} \mathrm{E}$ and $123^{\circ} \mathrm{E}$ and red circles are located between $123^{\circ} \mathrm{E}$ and $124.6^{\circ} \mathrm{E}$. Due to the paucity of data both groups of observed values are shown on both sections. 
Figure 10: E-W oriented tomographic cross-section at $22.24^{\circ} \mathrm{N}$ latitude, from global traveltime p-wave velocity model (Amaru, 2007; van Benthem et al., 2013; Hall and Spakman, 2015). Note the apparent tomographic thickness of the Philippine Sea plate (PSP) on either side of Gaugua Ridge is identical (about $70-80 \mathrm{~km}$ ).

\section{References :}

Amaru, M.L., 2007. Global travel time tomography with 3-D reference models in Geologica Ultaiectina, $\mathrm{PhD}$ thesis, http//igitur-archive.library.uu.nl/dissertations/2007-0202201924/index.htm

Ando, I., 1975. Source mechanisms and tectonic significance of historical earthquakes along the Nankai Trough, Japan. Tectonophysics 27, 119-140.

Chertova, M.V., Spakman, W., Geenen, T., van den Berg, A.P., and van Hinsbergen, D.J.J., 2014. Underpinning tectonic reconstructions of the western Mediterranean region with dynamic slab evolution from 3-D numerical modeling. J. Geophys. Res., 119 5876-5902, doi: 10.1002/2014JB011150.

Clague, J.J., 1997. Evidence for large earthquakes at the Cascadia subduction zone. Rev. Geophys., 35, 439-460.

Currie, C.A., Wang, K., Hyndman, R.D., and He, J., 2004. The thermal effects of steady-state slab-driven mantle flow above a subducting plate: the Cascadia subduction zone and backarc. Earth Planet. Sci. Lett., 223, 35-48. doi: 10.1016/j.eps1.2004.04.020

Dadson, S.J., Hovius, N., Chen, H., Dade W.B., Hsieh, M.-L., Willett, S.D., Hu, J.-Y., Horng, M.-J., Chen, M.-C., Stark, C.P., Lague, D., and Lin, J.-C. 2003. Links between erosion, runoff variability and seismicity in the Taiwan orogen. Nature, 426, 648-651.

Deschamps, A., Lallemand, S., and Collot, J.-Y., 1998. A detailed study of the Gagua Ridge: a fracture zone uplifted during a plate reorganisation in the Mid-Eocene. Marine Geophysical Research 20, 403-423.

Deschamps, A., Monie, P., Lallemand, S., Hsu, S.K., Yeh, K.Y., 2000. Evidence for Early Cretaceous oceanic crust trapped in the Philippine Sea Plate. Earth and Planetary Science Letters 179 (3-4), 503-516.

Deschamps, A., and Lallemand, S., 2002. The West Philippine Basin; an Eocene to early Oligocene back arc basin opened between two opposed subduction zones. Journal of 
Geophysical Research 107 (B12), doi: 10.1029/2001jb001706.

Doo, W.-B., Hsu, S.-K., Yeh, Y.-C., Tsai, C.-H., Chang, C.-M., 2015. Age and tectonic evolution of the northwest corner of the West Philippine Basin. Mar. Geophys. Res., 36, 113 125, doi: 10.1007/s11001-014-9234-8.

Eakin, D.H., McIntosh, K.D., Van Avendonk, H.J.A., Lavier, L., 2015. New geophysical constraints on a failed subduction initiation: The structure and potential evolution of the Gagua Ridge and Huatung Basin. Geochem. Geophys. Geosystems, 16, doi:10.1002/2014GC005548.

Font, Y., Liu, C.-S., Schnurle, P., and Lallemand, S., 2001. Constraints on backstop geometry of the Southwest Ryukyu subduction based on reflection seismic data. Tectonophysics 333, $135-158$.

Font, Y., and Lallemand, S., 2009. Subducting oceanic high causes compressional faulting in southernmost Ryukyu forearc as revealed by hypocentral determinations of earthquakes and reflection/refraction seismic data. Tectonophysics 466 (3-4), 255-267.

Font, Y., Kao, H., Liu, C.-S., Chiao, L.-Y., 2003. A comprehensive 3D seismic velocity model for the eastern Taiwan-southernmost Ryukyu regions. Terrestrial, Atmospheric and Oceanic Sciences 14, 159-182.

Goldfinger C., Nelson C.H., and Johnson J.E., 2003. Holocene earthquake records from the Cascadia subduction zone and northern San Andreas fault based on precise dating of offshore turbidites. Annu. Rev. Earth Planet. Sci. 31, 555-77.

Hall R. and Spakman, W., 2015 Mantle structure and tectonic history of SE Asia, Tectonophysics, doi: 10.1016/j.tecto.2015.07.003.

Ho, C.-S., 1986. A synthesis of the geologic evolution of Taiwan. Tectonophysics 125, 1-16.

Hsu, S.-K., and Sibuet, J.-C., 2005. Earthquake off Japan could generate strong tsunami. Eos $86(17), 169-170$.

Huang, Z., Zhao, D., and Wang, L. 2015. P wave tomography and anisotropy beneath Southeast Asia: Insight into mantle dynamics. J. Geophys. Res., 120, 3, 1642-1666, doi: 10.1002/2015JB012098.

Hyndman, R.D., and K. Wang, 1995. The rupture zone of Cascadia great earthquakes from current deformation and the thermal regime. J. Geophys. Res., 100, 22133-22154.

Hyndman, R.D., M. Yamano, and K. Wang, 1995. Thermal constraints on the seismogenic portion of the southwestern Japan subduction thrust. J. Geophys. Res. 100, 15373-15392.

Jankaew, K., Atwater, B.F., Sawai, Y., Choowong, M., Charoentitirat, T., Martin, M.E., and Prendergast, A., 2008. Medieval forewarning of the 2004 Indian ocean tsunami in Thailand. Nature, 455, doi:10.1038/nature07373. 
Kao, H., 1998. Can great earthquakes occur in the southernmost Ryukyu Arc-Taiwan region?, Diqiu Kexue Jikan = TAO, Terrestrial, tmospheric and Oceanic Sciences, 9(3), 487-508.

Kao, H., Shen, S.-s. J.\&Ma, K.-F., 1998. Transition from oblique subduction to collision: earthquakes in the southernmost Ryukyu Arc-Taiwan region, J. geophy. Res., 103(B4), 72117229.

Klingelhoefer, F., Gutscher, M.-A., Ladage, S., Dessa, J.-X., Graindorge, D., Andre, D.F.C., Permana, H., Yudistira, T., and Chauhan, A., 2010. The limits of the seismogenic zone in the epicentral region of the 26 Dec. 2004 great Sumatra-Andaman earthquake: results from a seismic refraction and wide-angle reflection surveys and thermal modeling. Journal of Geophysical Research 115 (B01304), 1-23. doi:10.1029/2009JB006569.

Klingelhoefer, F., Berthet, T., Lallemand, S., Schnurle, P., Lee, C. S., Liu, C. S., and Theunissen, T., 2012. P-wave velocity structure of the southern Ryukyu margin east of Taiwan: Results from the ACTS wide-angle seismic experiment. Tectonophysics, 578, 50-62.

Konstantinou, K.I., Lee, S.J., Font, Y., Kao, H., 2011. Rupture at the flank of the subducted Gagua ridge: the 18 December 2001 earthquake (Mw 6.8) offshore eastern Taiwan. Physics of the Earth and Planetary Interiors 189 (1-2), 80-91.

Koulakov, I., Wu, Y.-M., Huang, H.-H., Dobretsov, N., Jakovlev, A., Zabelina, I., Jaxybulatov, K., and Cherov, V., 2014. Slab interactions in the Taiwan region based on the Pand S-velocity distributions in the upper mantle. J. Asian Earth Sci., 79, 53-64, doi:10.1016/j.jseaes.2013.09.026.

Kumagai H., 1996. Time sequence and recurrence models for large earthquakes along the Nankai trough revisited. Geophys. Res. Lett. 23, 1139-42.

Lallemand, S.E., Font, Y., Bijwaard, H., Kao, H., 2001. New insights on 3-D plates interaction near Taiwan from tomography and tectonic implications. Tectonophysics 335 (34), 229-253.

Lallemand, S., Liu, C.-S., Dominguez, S., Schnürle, P., and Malavieille, J., 1999. Trenchparallel stretching and folding of forearc basins and lateral migration of the accretionary wedge in the southern Ryukyus; a case of strain partition caused by oblique convergence. Tectonics 18 (2), 231-247.

Lallemand, S., Theunissen, T., Schnürle, P., Lee, C.-S., Liu, C.-S., and Font, Y., 2013. Indentation of the Philippine Sea plate by the Eurasia plate in Taiwan: Details from recent marine seismological experiments. Tectonophysics 594, 60-79.

Langston, C.A., Lee, W.H.K., Lin, C.-J., and Liu, C.-C., 2009. Seismic-wave strain, rotation, and gradiometry for the 4 March 2008 TAIGER explosions. Bulletin of the Seismological Society of America 99 (2B), 1287-1301. 
Lay, T., 2015. The surge of great earthquakes from 2004 to 2014. Earth Planet. Sci. Lett., 409, 133-146, doi:10.1016/j.epsl.2014.10.047

Lay, T., H. Kanamori, Ammon, C.J., Nettles, M., Ward, S.N., Aster, R.C., Beck, S.L., Bilek, S.L., Brudzinski, M.R., Butler, R., DeShon, H.R., Ekstrom, G., Satake, J., and Sipkin, S., 2005. The Great Sumatra-Andaman earthquake of 26 December 2004. Science 308, $1127-$ 1133.

Lee, C.-S., Shor, G.G., Bibee, L.D., Lu, R.S., and Hilde, T.W.C., 1980. Okinawa Trough: origin as backarc basin. Marine Geology 35, 219-241.

Lester, R. and McIntosh, K.D., 2012. Multiple attenuation in crustal-scale imaging: examples from the TAIGER marine reflection dataset. Mar. Geophys. Res., 33, 289-305, doi: $10.1007 / \mathrm{s} 11001-012-9149-1$

Leyden, R., Ewing, M., and Murauchi, S., 1973. Sonobuoy refraction measurements in East China Sea. American Association of Petroleum Geologists Bulletin 57 (12), 2396-2403.

Lin, J.-Y., Hsu, S.-K., Sibuet, J.-C., 2004. Melting features along the western Ryukyu slab edge (northeast Taiwan); tomographic evidence. Journal of Geophysical Research 109 (B12), 15 .

Lin, J.-Y., Sibuet, J.-C., Hsu' S.-K. and Wu, W.-N., 2014. Could a Sumatra-like megathrust earthquake occur in the south Ryukyu subduction zone? Earth, Planets and Space, 66:49 doi:10.1186/1880-5981-66-49

Louden, K., 1980. The crustal and lithospheric thicknesses of the Philippine Sea as compared to the Pacific. Earth and Planetary Science Letters 50, 275-288.

Ludwig, W.J., Kumar, N., and Houtz, R.E., 1979. Profiler-sonobuoy measurements in the South China Sea Basin. Journal of Geophysical Research 84 (B7), 3505-3518.

Malavieille, J., and Trullenque, G., 2009. Consequences of continental subduction on forearc basin and accretionary wedge deformation in SE Taiwan: insights from analogue modeling. Tectonophysics 466, 377-394.

Malavieille, J., Lallemand, S.E., Dominguez, S., Deschamps, A., Lu, C.-Y., Liu, C.-S., Schnurle, P., Angelier, J., Collot, J.Y., and the ACT scientific crew, 2002. Arc-continent collision in Taiwan; new marine observations and tectonic evolution. Geological Society of America Special Paper 358, 187-211.

McCaffrey, R., 2008. Global frequency of magnitude 9 earthquakes. Geology, 36, p. 263-266. doi: $10.1130 / \mathrm{G} 24402 \mathrm{~A} .1$

McIntosh, K. D., van Avendonk, H.J.A. Lavier, L., Lester, R.M., Eakin, D., Wu, F., Liu, C.-S. and Lee, C.-S., 2013. Inversion of a hyper-extended rifted margin in the southern Central Range of Taiwan, Geology, 41, 871-874. 
Metois, M., Soquet, A., and Vigny, C., 2012. Interseismic coupling, segmentation and mechanical behavior of the Central Chile subduction zone. J. Geophys. Res. B03406, doi:10.1029/2011JB008736.

Monecke, K., Finger, W., Klarer, D., Kongko, W., McAdoo, B.G., Moore, A.L., and Sudrajat, S.U., 2008. A 1,000-year sediment record of tsunami recurrence in northern Sumatra. Nature, 455, doi:10.1038/nature07374.

Moreno, M., Rosenau, M., and Oncken, O., 2010. 2010 Maule earthquake slip correlates with pre-seismic locking of Andean subduction zone. Nature, 467, doi:10.1038/nature09349.

Murauchi, S., Den, N., Asano, S., Hotta, H., Yoshii, T., Asanuma, T., Hagiwara, K., Ichikawa, K., Sato, T., Ludwig, W.J., Ewing, J.I., Edgar, N.T., and Houtz, R.E., 1968. Crustal structure of the Philippine Sea. Journal of Geophysical Research 73, 3143-3171.

Nakamura, M., 2004. Crustal deformation in the central and southern Ryukyu Arc estimated from GPS data. Earth and Planetary Science Letters 217 (3-4), 389-398.

Nakamura, M., 2009. Aseismic crustal movement in the southern Ryukyu Arc, southwest Japan. Geophysical Research Letters 36, L20312, 389-398, doi:10.1029/2009GL040357

Oleskevich, D.A., Hyndman, R.D., and Wang, K. 1999. The updip and downdip limits to great subduction earthquakes: Thermal and structural models of Cascadia, south Alaska, SW Japan, and Chile J. Geophys. Res., 104, 14,965-14,991.

Pacheco J.F., Sykes L.R., and Scholz C.H., 1993. Nature of seismic coupling along simple plate boundaries of the subduction type. J. Geophys. Res., 98, 14,133-14,159

Satake K., Shimazaki K., Tsuji Y., and Ueda K., 1996. Time and size of a giant earthquake in Cascadia inferred from Japanese tsunami records of January 1700. Nature 379, 246-49.

Seno, T., Stein, S., and Gripp, A., 1993. A model for the motion of the Philippine Sea plate 591 consistent with NUVEL-1 and geological data. Journal Geophys. Res., 592 98, 17,94117,948 .

Sibuet, J.-C., Deffontaines, B., Hsu, S.-K., Thareau, N., Le Formal, J.-P., Liu, C.-S., and the ACT Scientific Party, 1998. Okinawa Trough backarc basin: Early tectonic and magmatic evolution. J. Geophys. Res. 103, 30,245-30,267.

Stein, S., and Okal, E.A., 2005. Speed and size of the Sumatra earthquake, Nature, 434, 581582.

Stein, C.A., and S. Stein, 1992. A model for the global variation in oceanic depth and heat flow with lithospheric age. Nature, 359, 123-126.

Suppe, J., 1981. Mechanics of mountain building and metamorphism in Taiwan. Memoir of the Geological Society of China 4, 67-89. 
Teng, L.S., Lee, C.T., Tsai, Y.B., Hsiao, L.Y., 2000. Slab breakoff as a mechanism for flipping of subduction polarity in Taiwan. Geology 28 (2), 155-158.

Tichelaar, B.W., and Ruff, L.J. 1993. Depth of seismic coupling along subduction zones, J. Geophys. Res., 98, 2017-2037.

Theunissen, T., Y. Font, S. Lallemand, and W.T.Liang. 2010. The largest instrumentally recorded earthquake in Taiwan: revised location and magnitude, and tectonic significance of the 1920 event, Geophys. J. Int., 183, 1119-1133, doi :101111/j.1365-246X.2010.04813.x.

Theunissen, T., Y. Font, S. Lallemand, and S. Gautier. 2012a Improvements of the Maximum Intersection Method for 3D absolute earthquake location, BSSA, vol.102-4, August 2012, 1764-1785, doi: 10.1785/0120100311.

Theunissen, T., Lallemand, S., Gautier, Y. F. S., Lee, C.-S., Liang, W. T., Wu, F., and Berthet, T., 2012b. Crustal deformation at the southernmost part of the Ryukyu subduction (East Taiwan) as revealed by new marine seismic experiments. Tectonophysics 578, 10-30. doi:10.1016/j.tecto.2012.04.011

Tsai, Y.-B., 1986. Seismotectonics of Taiwan. Tectonophysics 125, 17-37.

Van Avendonk, H.J.A., Kuo-Chen, H., McIntosh, K.D., Lavier, L.L., Okaya, D.A., Wu, F.T. Wang, C.Y. Lee, C.-S. and Liu, C.-S., 2014. Deep crustal structure of an arc-continent collision: Constraints from seismic travel times in central Taiwan and the Philippine Sea, J. Geophys. Res., 119, 8397-8416, doi:10.1002/2014JB011327.

van Benthem, S., Govers, R., Spakman, W., and Wortel, R., 2013. Tectonic evolution and mantle structure of the Caribbean. J. Geophys. Res., 118, 3019-3036, doi: 10.1002/jgrb.50235

Wada, I., Wang, K., He, J., and Hyndman, R.D., 2008. Weakening of the subduction interface and its effects on surface heat flow, slab dehydration, and mantle wedge serpentinization. J. Geophys. Res., 113, B04402, doi:10.1029/2007JB005190

Wada, I., and Wang, K., 2009. Common depth of slab-mantle decoupling: Reconciling diversity and uniformity of subduction zones. Geochem., Geophys., Geosyst., 10, Q10009, doi:10.1029/2009GC002570

Wang, K.L. Hyndman, R.D., M. Yamano, and 1995. Thermal regime of the southwest Japan subduction zone - effects of the age history of the subducting plate. Tectonophys., 248, 53-69.

Wang, T.K., Mcintosh, K., Nakamura, Y., Liu, C.-S., Chen, H.-W., 2001. Velocity-interface structure of the southwestern Ryukyu subduction zone from EW9509-1 OBS/MCS 602 data. Marine Geophysical Research, 22, 265-287.

Wang, T.K., Lin, S.-F., Liu, C.-S., Wang, C.-S., 2004. Crustal structure of the southernmost Ryukyu subduction zone: OBS, MCS and gravity modelling. Geophysical Journal International 157, 147-163. 
Wei, W., Zhao, D., Xu J., Wei, F. and Liu, G. 2015. P and S wave tomography and anisotropy in Northwest Pacific and East Asia: Constraints on stagnant slab and intraplate volcanism. J. Geophys. Res., 120, 3, 1642-1666, doi: 10.1002/2014JB011254.

Wessel, P., and Smith, W.H.F., 1995. A new version of the Generic Mapping Tool (GMT). Eos, Transactions, American Geophysical Union, 76, 329.

Wu, F.T., Rau, R.J., Salzberg, D., 1997. Taiwan orogeny: thin skinned or lithospheric collision. Tectonophysics 274, 191-220, doi: 10.1016/S0040-1951(96)00304-6.

Yang, Y.-S., and Wang, T.K., 1998. Crustal velocity variation of the Philippine Sea Plate from TAICRUST OBS/MCS Line 23. TAO 9, 379-393.

Yeh, Y.H., Shih, R.C., Lin, C.H., Liu, C.C., Yen, H.Y., Huang, B.S., Liu, C.S., Chen, P.Z., Huang, C.S., Wu, C.J., and Wu, F.T., 1998. Onshore/offshore wide-angle deep seismic profiling in Taiwan. TAO 9, 301-316.

Yu, S.B., Chen, H.Y., and Kuo, L., 1997. Velocity field of GPS stations in the Taiwan area. Tectonophysics 274 (1-3), 41-59.

Zelt, C.A., 1999. Modelling strategies and model assessment for wide-angle seismic traveltime data, Geophys. J. Int. 139, 183-204.

Zelt, C.A., and Ellis, R. M., 1988. Practical and efficient ray tracing in two-dimensional media for rapid traveltime and amplitude forward modeling. Can. J. Explor. Geophys, 24(1), $16-31$.

Zelt, C.A., and Smith, R.B., 1992. Seismic travel time inversion for 2-d crustal velocity structure. Geophysical Journal International 108, 16-31. 


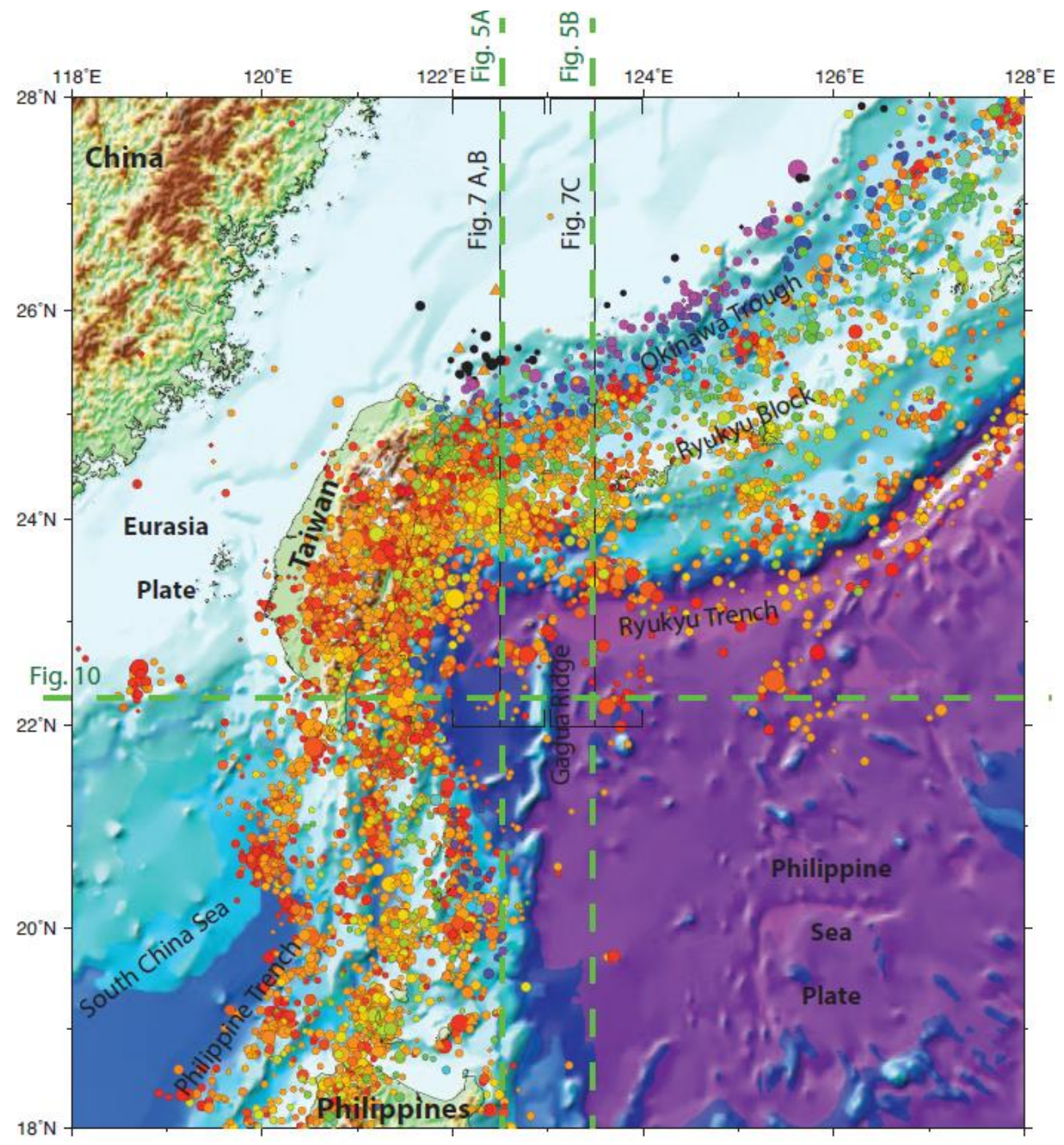

Figure 1 


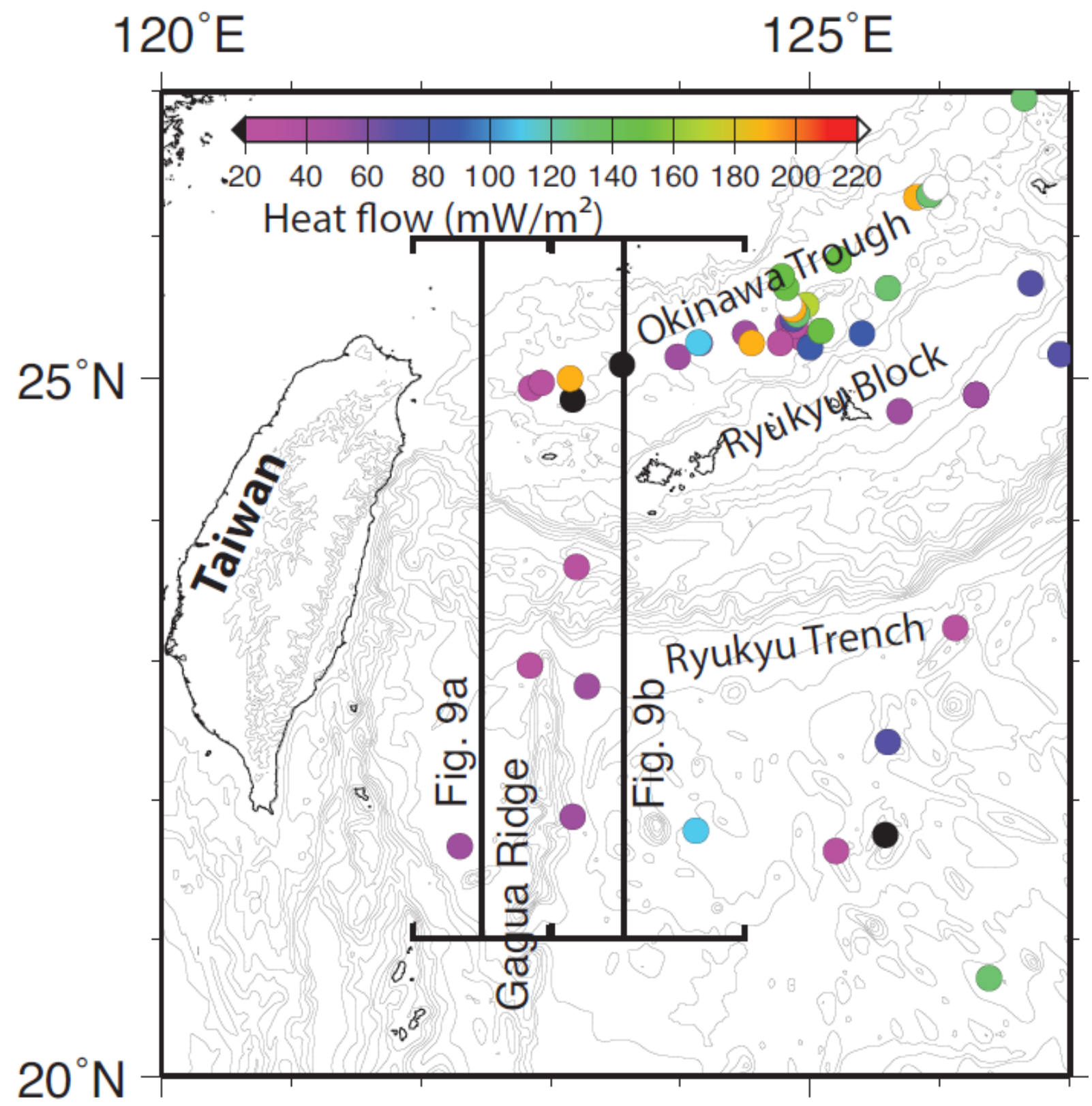

Figure 2 


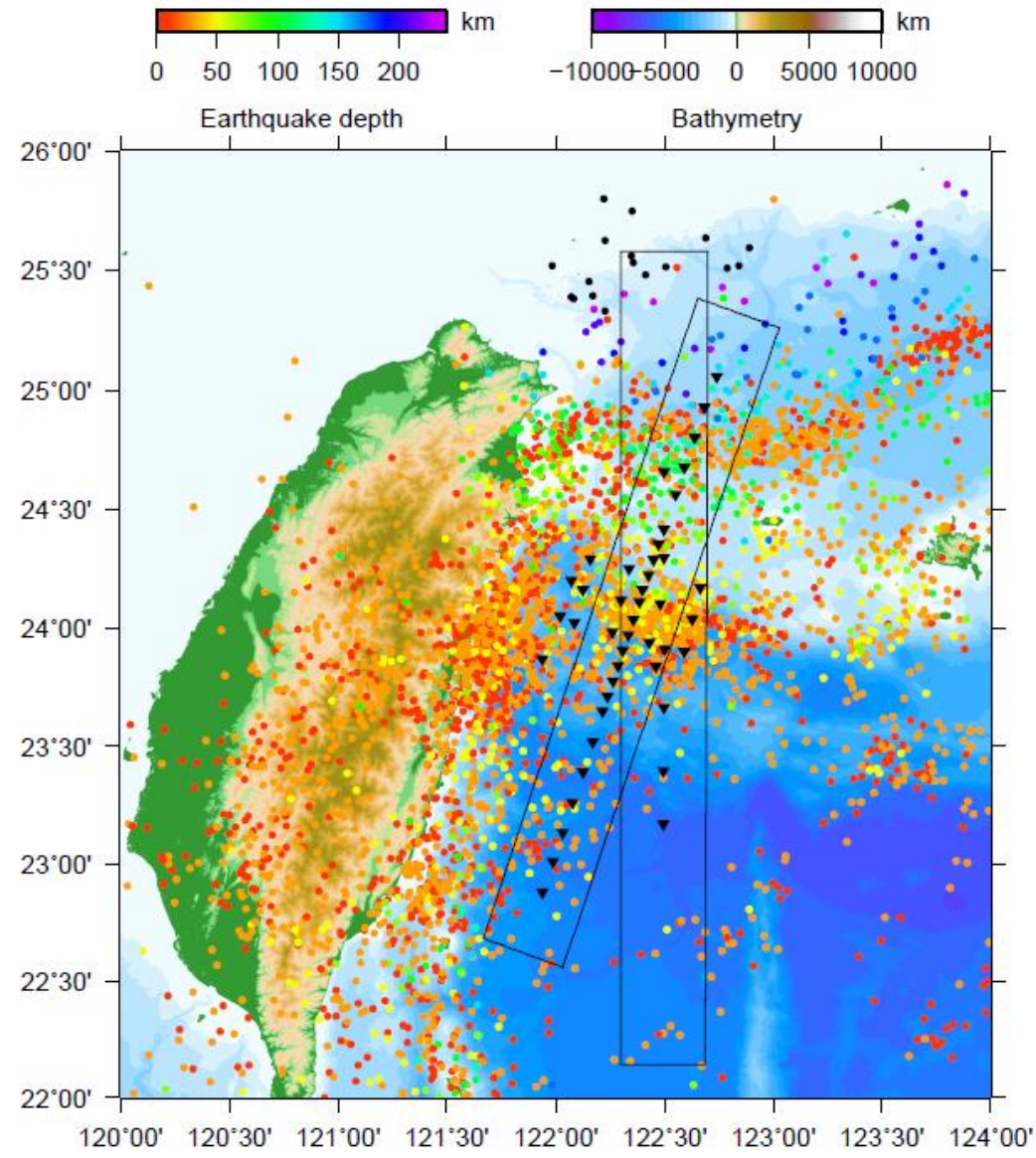

Figure 3 

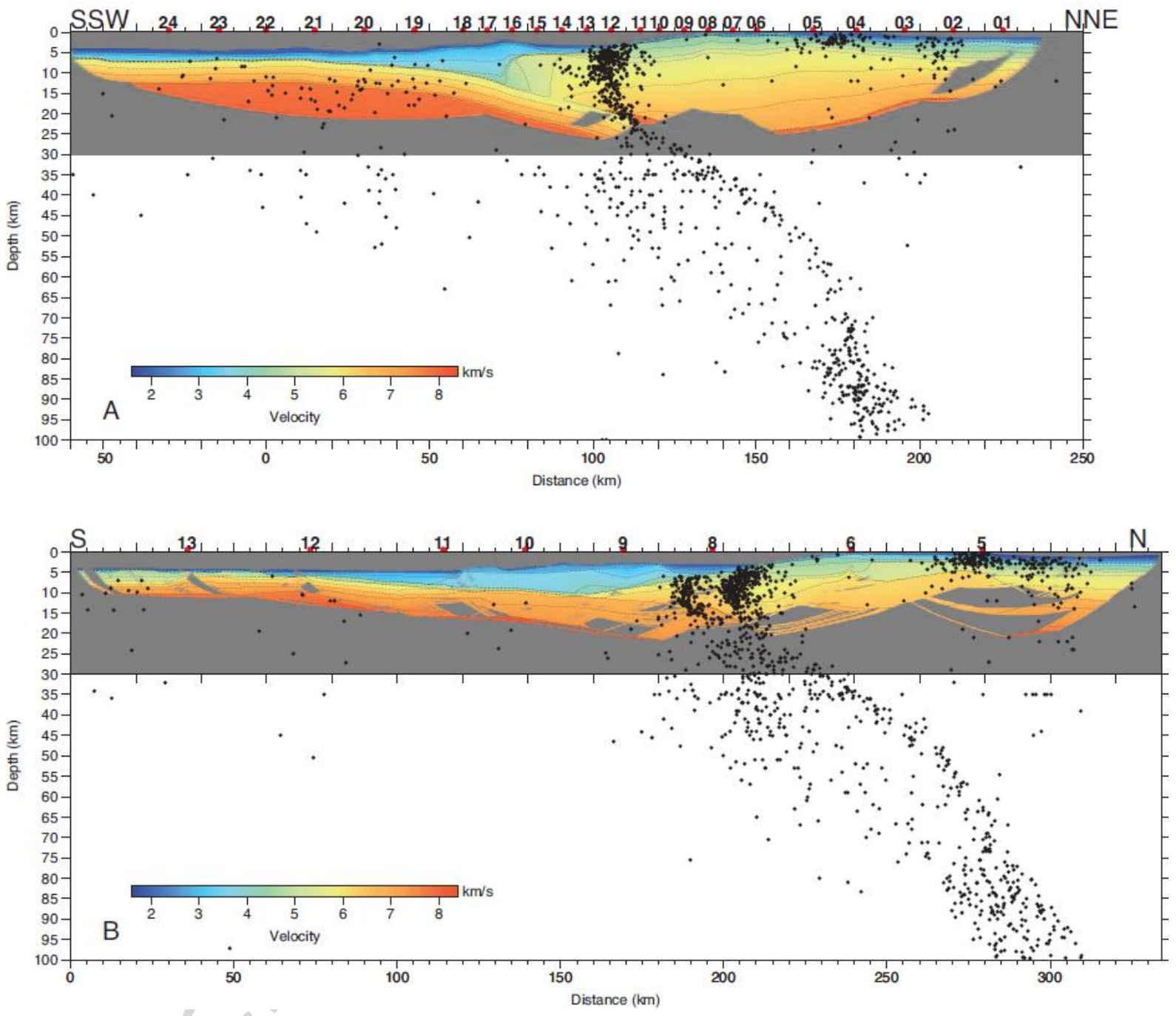

Figure 4 

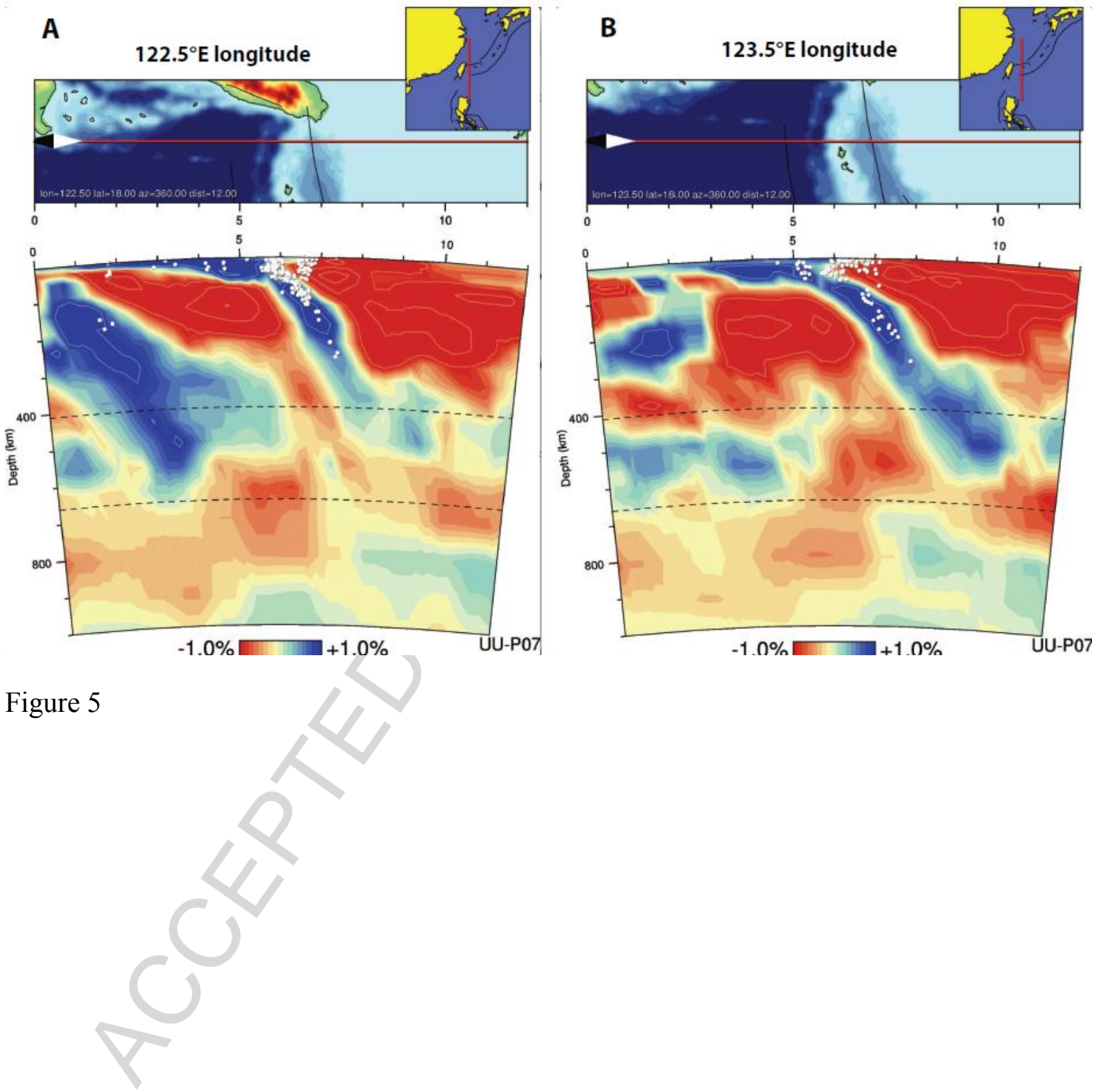

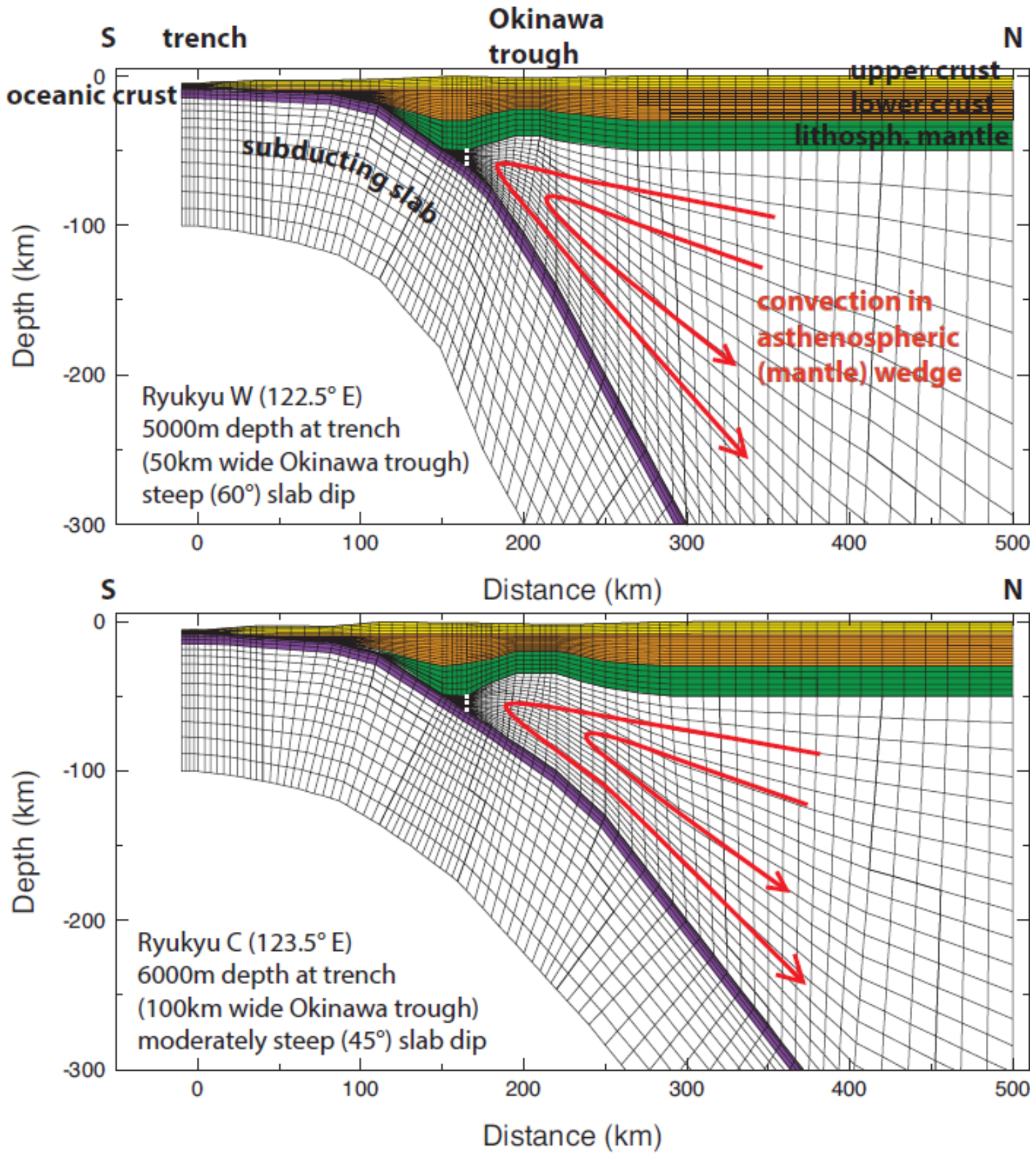

Figure 6 


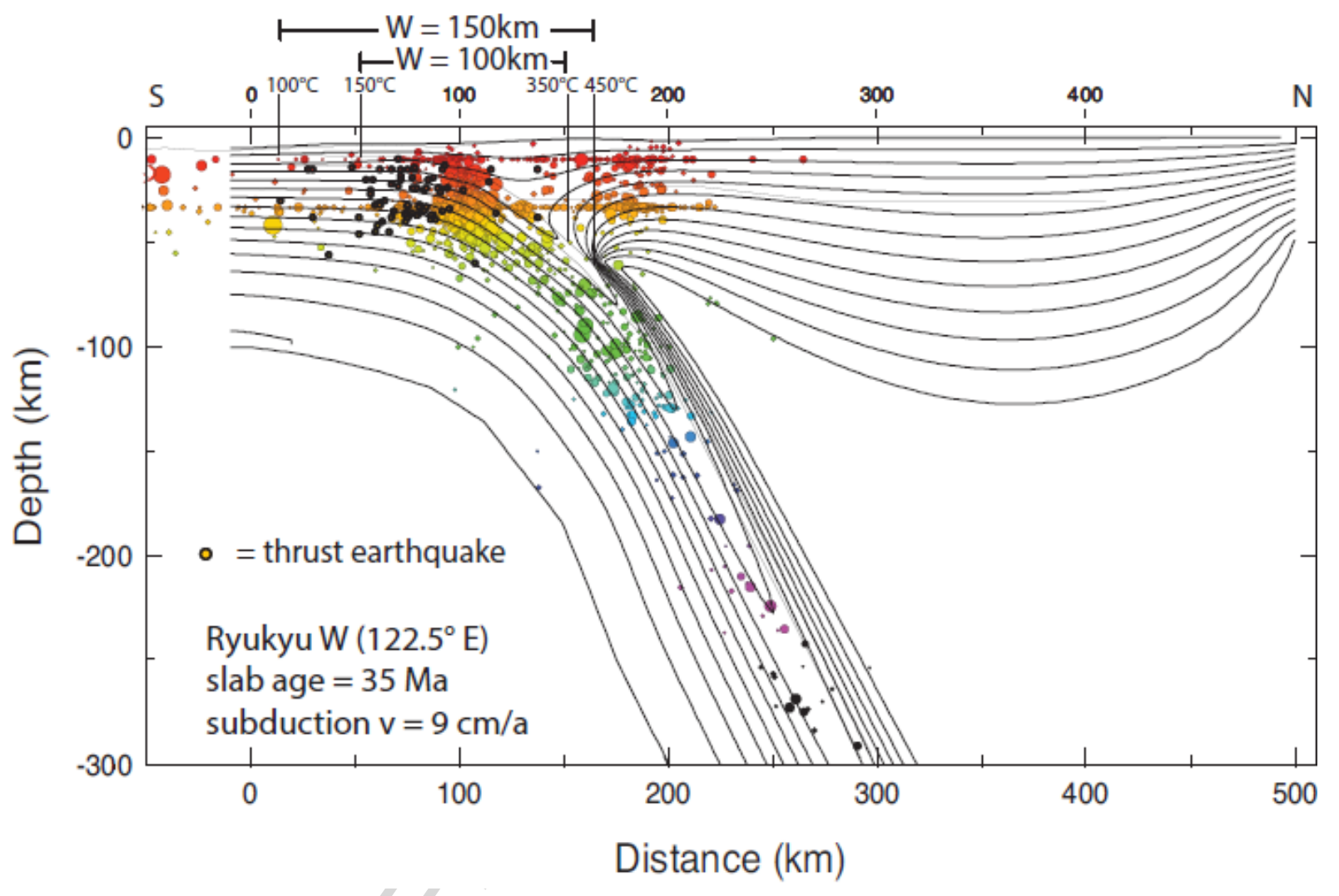

Figure 4a 


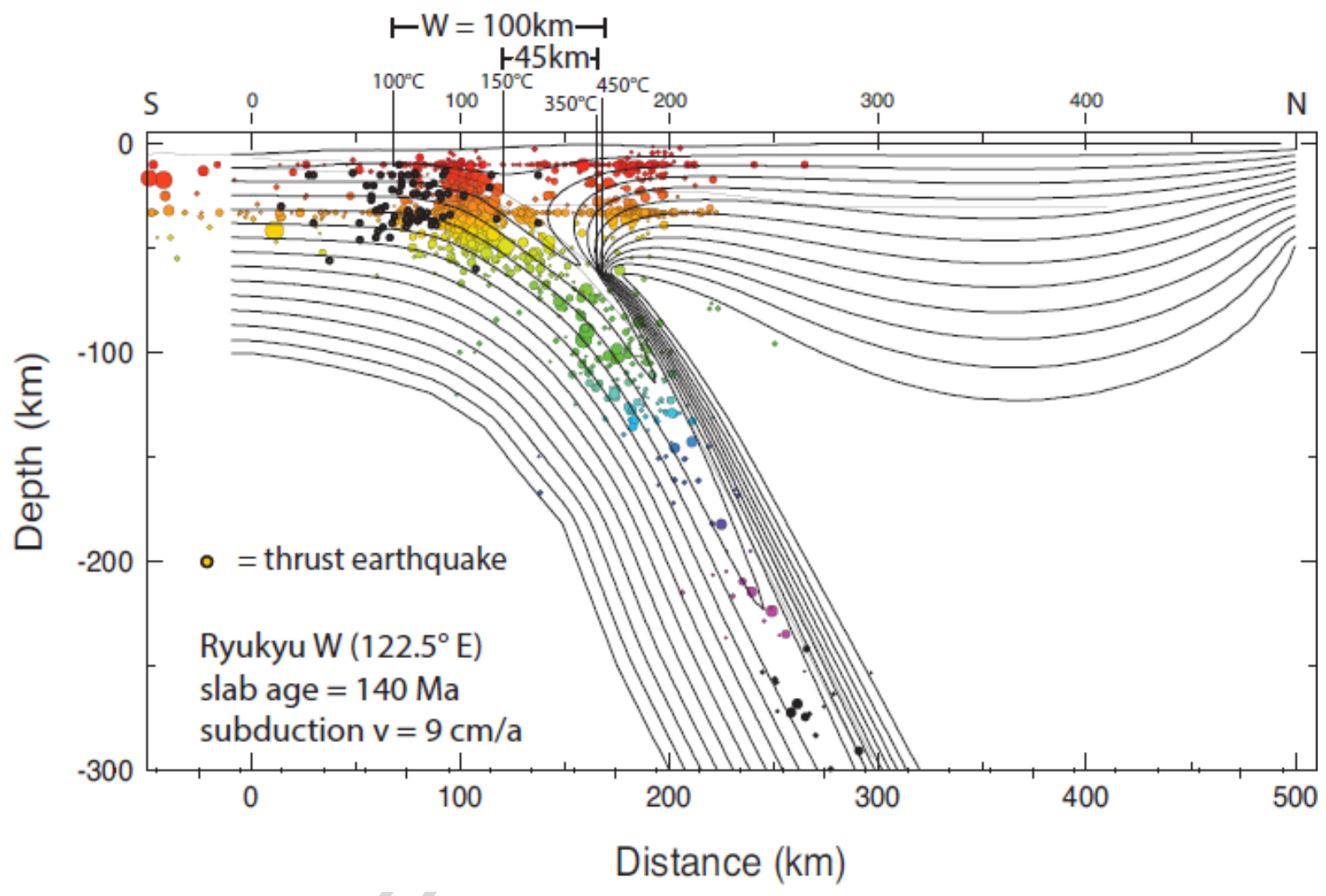

Figure $7 b$ 


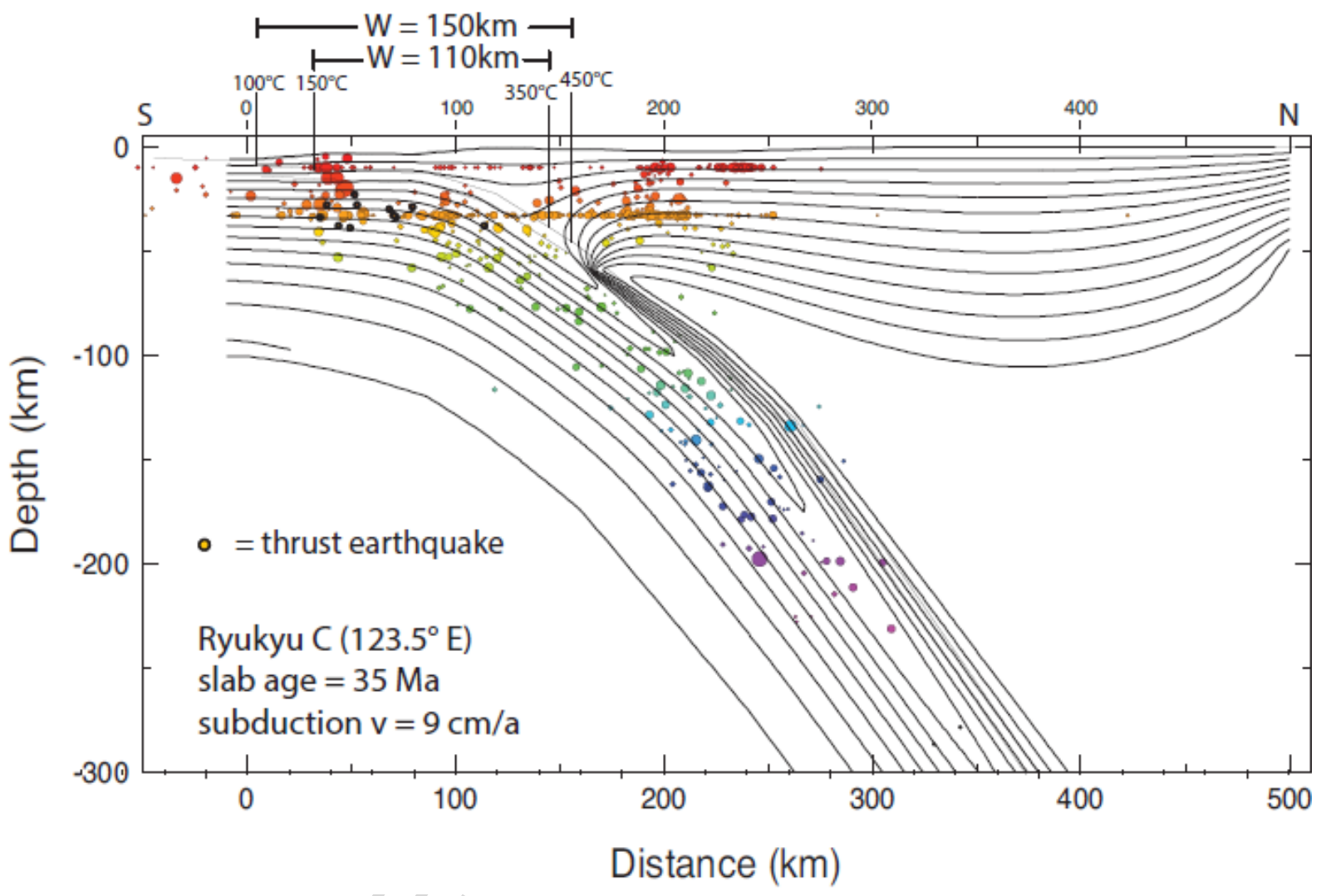

Figure 7c 


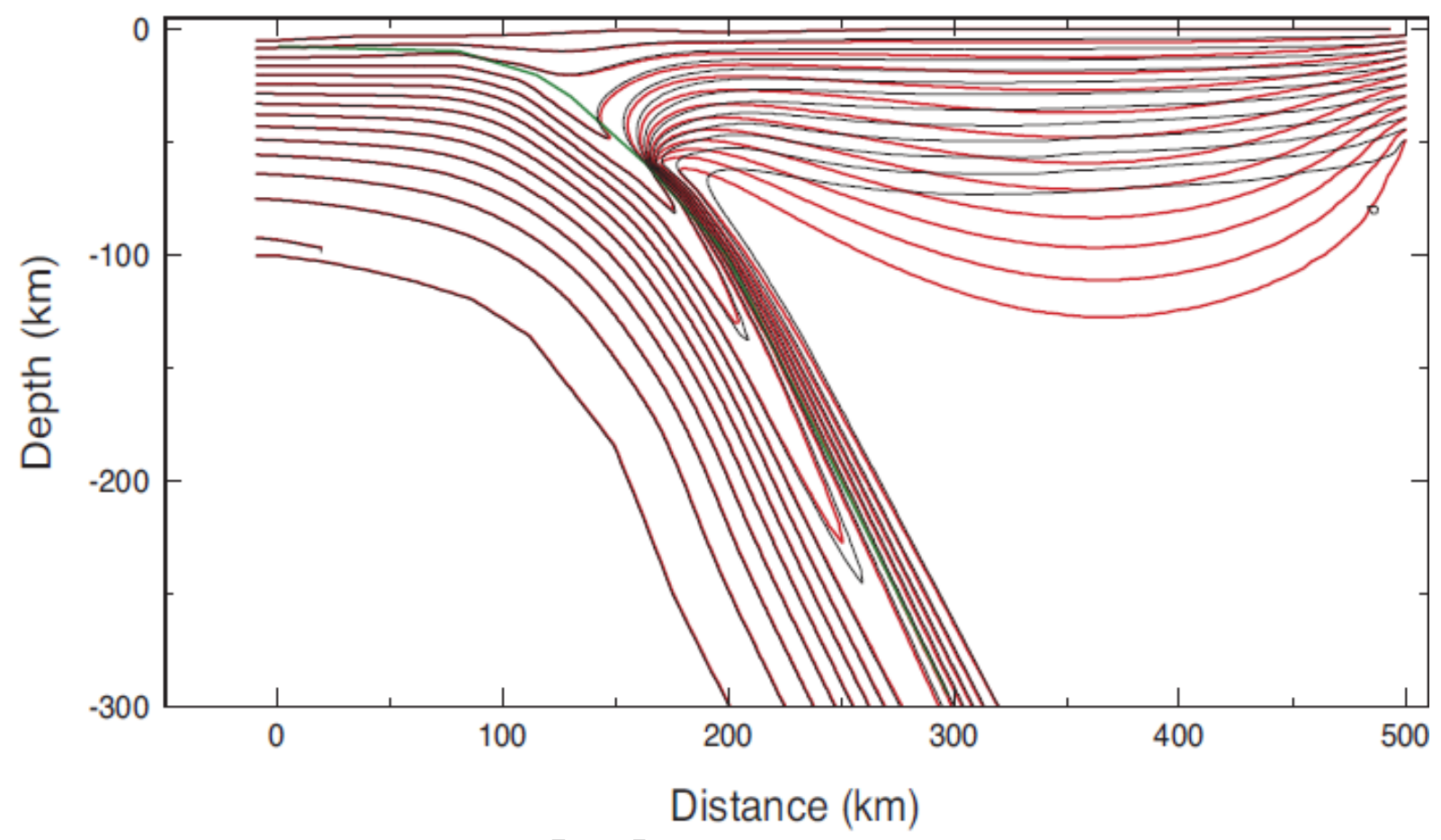

Figure 8 


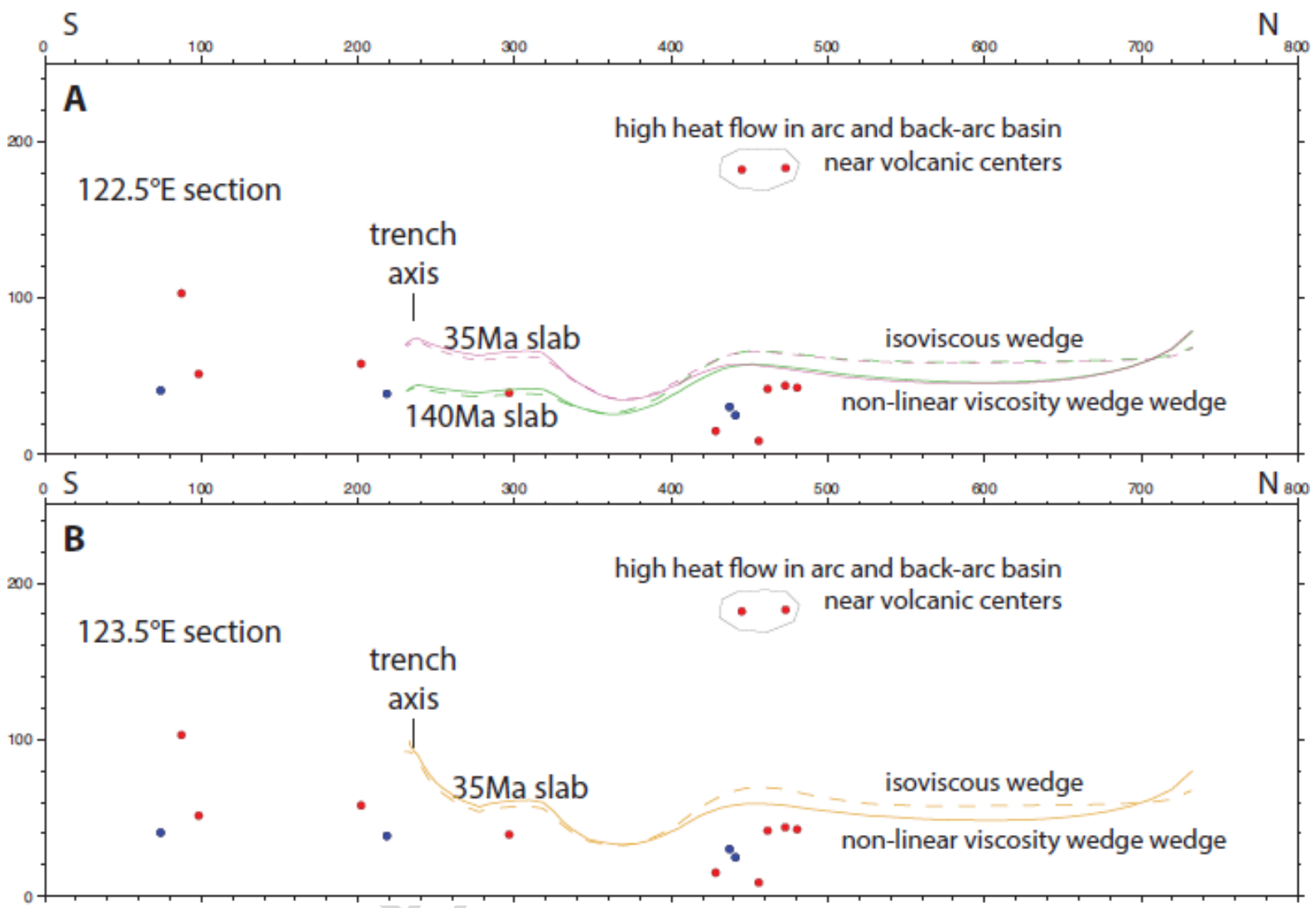

Figure 9 


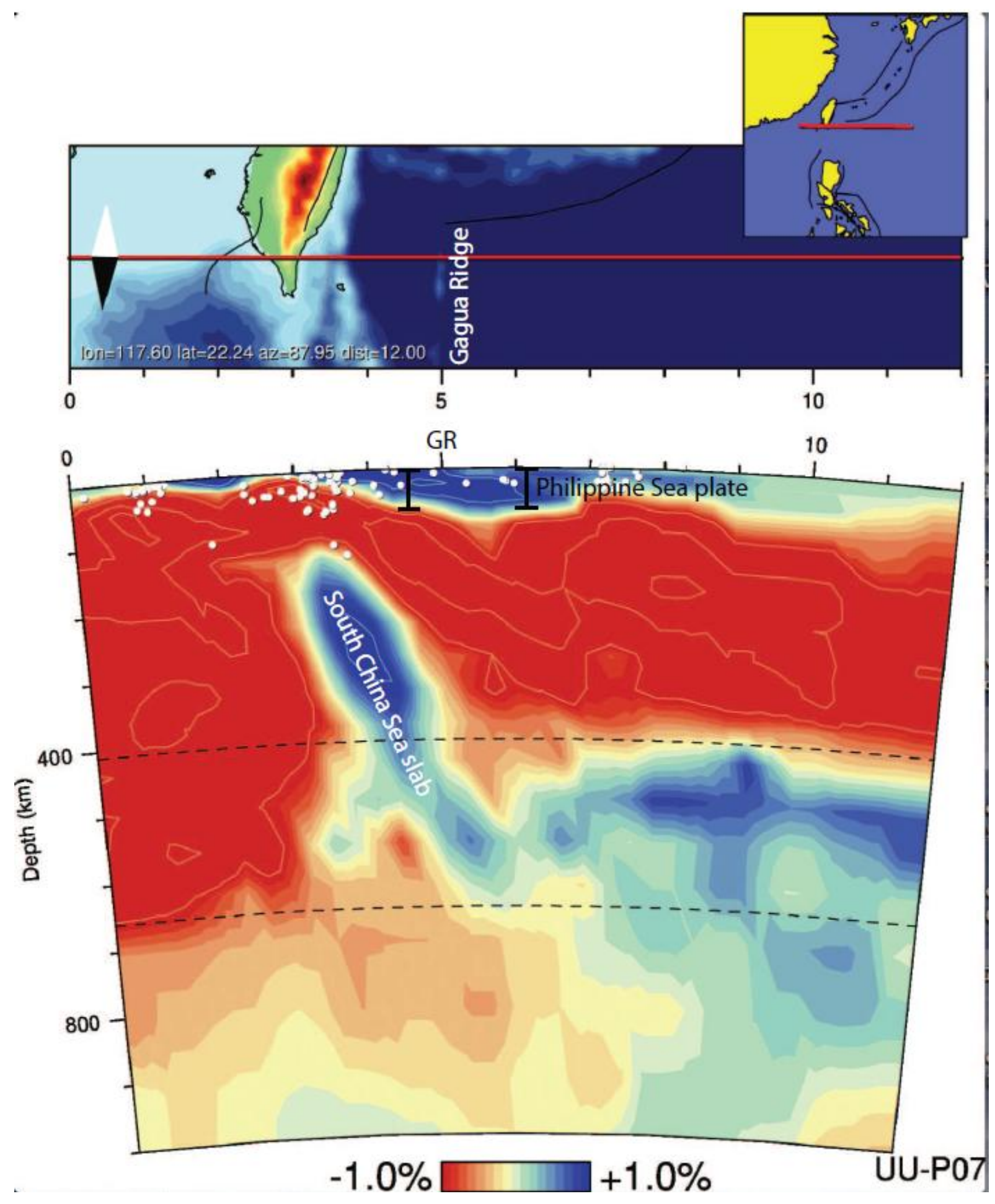

Figure 10 